\title{
Compensation, Work Discipline and Work Motivation Relationship to Employee Job Satisfaction
}

\author{
Imam Abrori ${ }^{1}$, Nuril Hidayati ${ }^{2}$ \\ ${ }^{12}$ Department of Management, STIE Widya Gama Lumajang \\ Faculty of Economics, Department of Management, Muhammadiyah University of Jember
}

Email: ari.abrorii@gmail.com

A R T ICLE INFO

Date of entry:

24 April 2020

Revision Date:

10 May 2020

Date Received:

13 May 2020

\begin{abstract}
A B S T R A C T
This study aims to determine: (1) the influence of the compensation variable on job satisfaction (2) the influence of the variable work discipline on job satisfaction (3) about the effect of work motivation on employee job satisfaction at PT. PP Perkebunan Jember Widodaren. This research is a causal associative study using a quantitative approach. The population in this study were employees of PT. PP Perkebunan Jember Widodaren amounting to 69 people. The sampling technique in this research is census. Data were collected using a questionnaire that had been tested for linearity, multicolonierity and heteroscedasticity tests. The data analysis technique used is multiple regression. The results of this research are at the significant level 5\% indicates that: (1) Compensation has a positive and significant effect on employee job satisfaction. This is evidenced by the beta coefficient ( $\beta$ ) $0,227(p<0,05 ; p=0,042)$ and the effect of compensation on employee job satisfaction with a significant level of 0,003 (2) Work motivation has a positive but not significant effect on employee job satisfaction as evidenced by the level of significance of 0,394 .
\end{abstract}

Keywords: Compensation, Work Discipline, Work Motivation, Job Satisfaction

Cite this as: Abrori, I., Hidayati, N. (2020). Compensation, Work Discipline and Work Motivation Relationship to Employee Job Satisfaction. Jurnal Ilmu Manajemen Advantage. 4(1), 32-39. https://doi.org/10.30741/adv.v4i1.603

\section{INTRODUCTION}

In this modern era, the management of human resources is very important for companies in running their business. In order for the company's goals to be achieved effectively and efficiently, the company must be able to manage existing human resources to work productively . The rapid business growth has made competition in the business world even tighter, including the plantation business . Now companies not only have to be smart in acquiring consumers, but also have to be smart in keeping consumers loyal to buy or consume company products to increase company value . Given the importance of this, companies must be able to spur human resources who act as executors and managers of the company's business so that they are enthusiastic in carrying out their duties. The adoption of appropriate human resource management concepts and techniques is 
a key strategy in human resource management, one of which is through compensation management, work discipline, work motivation, and job satisfaction. Some research found that the impact of job satisfaction more on employee productivity, levels of absenteeism and employee turnover. The more aspects of work that are in accordance with individual desires, the higher the level of satisfaction felt, and vice versa according to Megawati (2005).

In addition, the growth of work motivation is also a factor that affects employee satisfaction in carrying out their duties. Motivation high employment, the employee will work harder in the conduct of its work. On the other hand, with low work motivation, employees do not have enthusiasm for work, give up easily, and have difficulty completing their work (Siagian, 2012: 52). This means that motivation has a positive impact on job satisfaction, this is in accordance with Armstrong's opinion which states that "The relationship between motivation and job satisfaction is something positive", increased motivation will result in more effort in better job satisfaction, and vice versa (Armstrong, 2005: 43).

The statement was in harmony with the results of research Astuti and Sudharma (2013) states that compensation and motivation have a significant effect on job satisfaction, Ekayadi (2 009 ) states that motivation affects the significant on job satisfaction, and Arina (2015) prove the work discipline influential to $\mathrm{k}$ job satisfaction. Based on previous research that has shown partial influence of the compensation, motivation, and discipline to job satisfaction, then research gap first of this study was to test the simultaneous influence of compensation, motivation, and discipline to job satisfaction. Second, there is a research gap in the research conducted by Louis Agung Widyarto (2012) which proves different results, that compensation and motivation have no effect on employee job satisfaction. Therefore, research on the causal relationship between compensation, motivation, and discipline on job satisfaction still has to be done to increase scientific insight and knowledge in the field of human resource management, especially regarding the influence of the four variables tested.

PT.PP. Widodaren Plantation operates in East Java with the Head Office of PTPP Jember Indonesia at jl. Gajah Mada No. 174 Jember, has 8 business units (gardens) that produce: (a) Robusta coffee, (b) Edel cocoa, (c) Bulk cocoa, (d) Rubber, (e) cloves, (f) pepper and plants outside the main business ( $\mathrm{g}$ ) sengon wood and horticulture in plantations. PT. PP. Widodaren Plantation has 269 employees, consisting of various divisions and fields. In implementing human resource management, PT. PP. The Widodaren Jember Plantation has tried to create employee job satisfaction, but it seems that there are still many problems so that the fulfillment of employee job satisfaction is not maximally achieved and this has an impact on the difficulty of achieving organizational goals. The problems faced by PT.PP Perkebunan Widodaren Jember include the lack of employee productivity in meeting production targets caused by weather factors , communication between employees that is not optimal, lack of employee discipline such as arriving late when going to work, taking breaks before their time and absent from work without No clarity or permit, so cause job satisfaction of employees decreased. This is none other than caused by several factors, namely the level of discipline and low motivation growth which results in decreased productivity of employee performance and organizational goals are not well met.

Siagian (2012: 295) in his book entitled human resource management says that low work motivation can affect employee performance that is not optimal. Circumstances in PT.PP Plantation Widodaren Jember, particularly in the application of labor discipline can be seen in the data absenteeism following this : 
Table 1 . Attendance Data for PT.PP Perkebunan Widodaren Factory Employees 2019

\begin{tabular}{lccccc}
\hline \multicolumn{1}{c}{ Month } & Paid leave & Sick & Alpa & Present & Employe \\
\hline January & 8 & 5 & 2 & 54 & 69 \\
February & 9 & 10 & 0 & 50 & 69 \\
March & 5 & 4 & 1 & 59 & 69 \\
April & 8 & 8 & 0 & 53 & 69 \\
May & 4 & 4 & 2 & 59 & 69 \\
June & 7 & 6 & 0 & 56 & 69 \\
July & 4 & 3 & 1 & 61 & 69 \\
August & 8 & 1 & 0 & 60 & 69 \\
Sebtember & 6 & 3 & 3 & 57 & 69 \\
October & 6 & 5 & 0 & 58 & 69 \\
November & 4 & 2 & 3 & 60 & 69 \\
December & 7 & 4 & 1 & 57 & 69 \\
Amount & 76 & 55 & 13 & 684 & 828 \\
\hline
\end{tabular}

Source: PT.PP Perkebunan Widodaren Jember, Employee Attendance in 2019

Based on table 1. it can be seen that the employee attendance rate is not in accordance with the provisions and demands of the company. The company wants the best possible employee attendance level so that the company is able to achieve production targets according to planning . Therefore, research on compensation, discipline, work motivation and job satisfaction which can affect the level of attendance of employees at PT. PP Perkebunan Widodaren Jember felt that it was necessary. This study aims to determine the effect of compensation, discipline, work motivation on job satisfaction either simultaneously or partially.

\section{METHODS}

This research uses quantitative methods. Quantitative research is the process of discovering knowledge using the data in the form of numbers as a means of analyzing the information about what you want to be known (Kasiram (2008: 149). Research method is Causal Comparative which examined the causal relationship is the relationship of compensation, work discipline, and motivation work on Job Satisfaction. the population in this study using census method that all employees and is still actively working on plantations PT.PP Widodaren Jember many as 69 that is 62 people men and 7 women.

The method of analysis in this study is multiple linear regression analysis. The purpose of multiple linear regression analysis is to test and comprehensively determine the effect of independent variables on the dependent variable. First, an instrument test is carried out which aims to determine whether the research data is valid, reliable, and normal as follows: if the statement in the questionnaire is able to reveal something that can be measured what is being measured, then the data can be declared valid. The use of the validity test is to compare the calculated $r$ value with the $r$ table value. If the value of $r$ count $>r$ table and is positive then the per real late is said to be valid (Ghozali, 2009). After the validity test, performed test reliability which is used to measure a questionnaire is a indicator of variables. If the respondent's answer to the statement in the questionnaire is stable, then the data can be said to be reliable or reliable . Reliability test is done by knowing the value of Cronbach alpha $>0.60$. furthermore do $\mathrm{u}$ ji normality whose purpose it is to test whether the regression model, the confounding variable or residul have a normal distribution. Detection is done by looking at the distribution of data (points) on the diagonal axis of the graph on the basis of decision making: 1. If the data spreads around the diagonal line and follows the direction of the diagonal line or the histogram graph shows a normal distribution pattern, then the regression model meets the assumption of normality. 2. If the data spreads far from the diagonal and / or does not follow the direction of the diagonal line or the histogram graph 
does not show a normal distribution pattern, the regression model does not meet the normality assumption.

After the instrument test was carried out, it was continued with the classical assumption test as follows: Multicolonierity test aims to test whether the regression model found a correlation between independent variables. The multicollinearity test can be seen from the Variance Inflation Factor (VIF) value and its tolerance value. If the VIF value $<10$ and the tolerance value $>0.1$, the regression model is free from the multicollinearity of Ghozali (2009: 96). Furthermore, the heteroscedasticity test aims to test whether in the regression model there is an inequality of variance from the residuals of one observation to another. If the calculated significance value is greater than Alpha $=5 \%$, then there is no heteroscedasticity problem. But if the calculated significant value is less than Alpha $=5 \%$, it can be concluded that the regression model heteroscedasticity occurs (Ghozali: 2009). The next step is to test the hypothesis, namely the test or partial, which means testing one by one the independent variable against the dependent, and the F test or simultaneously, which means testing the whole independent variable on the dependent, and the test of determination, which measures how far the model's ability to explain variations in the dependent variable .

\section{RESULTS AND DISCUSSION}

Table 2. Validity Test Results

\begin{tabular}{ccccc}
\hline & \multicolumn{4}{c}{ Variable / Indicator } \\
\cline { 2 - 5 } No & Compensation & R Count & R table & Information \\
\hline 1 & P1 & 0,672 & 0.197 & Valid \\
2 & P2 & 0,733 & 0.197 & Valid \\
3 & P3 & 0,631 & 0.197 & Valid \\
& & Work Dicipline & & \\
1 & P4 & 0,675 & 0.197 & Valid \\
2 & P5 & 0,856 & 0.197 & Valid \\
3 & P6 & 0,785 & 0.197 & Valid \\
4 & P7 & 0,791 & 0.197 & Valid \\
4 & P8 & 0,776 & 0.197 & Valid \\
& & Work Motivation & & \\
1 & P9 & 0,599 & 0.197 & Valid \\
2 & P10 & 0,580 & 0.197 & Valid \\
3 & P11 & 0,842 & 0.197 & Valid \\
4 & P12 & 0,488 & 0.197 & Valid \\
5 & P13 & 0,662 & 0.197 & Valid \\
& & Job Satisfaction & & \\
1 & P14 & 0,691 & 0.197 & Valid \\
2 & P15 & 0,789 & 0.197 & Valid \\
3 & P16 & 0,743 & 0.197 & Valid \\
\hline
\end{tabular}

Source: SPSS output

From table 2 . it can be seen that $r$ count $>r$ table. Thus concluded that the item -Item statement declared invalid. 
Table 3. Reliability Test Results

\begin{tabular}{ccccc}
\hline Variable & Cronbach's Alpha & Cutt off & N of Item & Information \\
\hline X1 & 0,699 & $>0,6$ & 4 & Reliable \\
X2 & 0,886 & $>0,6$ & 4 & Reliable \\
X3 & 0,747 & $>0,6$ & 5 & Reliable \\
Y & 0,781 & $>0,6$ & 6 & Reliable \\
\hline
\end{tabular}

Source: SPSS output

Based on table 3. it can be seen that the value of Cronbach's Alpha X1, X2, X3, and Y > 0.60. So it can be concluded that the research data is declared reliable or feasible as a tool in data collection. Based on the results of data processing using SSS, it is known that the points are around the normal distribution line, so that the research data is normally distributed and there are no disturbances.

Table 4. Results of Multiple Linear Regression Analysis

\begin{tabular}{|c|c|c|c|c|c|c|}
\hline & \multirow[b]{2}{*}{ Model } & \multicolumn{2}{|c|}{$\begin{array}{l}\text { Unstandardized } \\
\text { Coefficients }\end{array}$} & \multirow{2}{*}{$\begin{array}{c}\text { Standardized } \\
\text { Coefficients }\end{array}$} & \multirow[b]{2}{*}{$\mathrm{t}$} & \multirow[b]{2}{*}{ Sig. } \\
\hline & & $\mathrm{B}$ & Std. Error & & & \\
\hline \multirow[t]{4}{*}{1} & (Constant) & 1,367 & 0,404 & & 3,379 & 0,001 \\
\hline & Compensation & 0,226 & 0,109 & 0,227 & 2,079 & 0,042 \\
\hline & Work Dicipline & 0,602 & 0,197 & 0,39 & 3,06 & 0,003 \\
\hline & Work Motivation & 0,136 & 0,158 & 0,111 & 0,859 & 0,394 \\
\hline
\end{tabular}

Source: SPSS Output

Based on the results of multiple linear regression analysis, the regression equation is obtained as follows: $\mathrm{Y}=\mathrm{a}+\mathrm{b}_{1} \mathrm{X}_{1}+\mathrm{b}_{2} \mathrm{X}_{2}+\mathrm{e}, \mathrm{Y}=1,367+0,226+0,602+0,136$. Information: $\mathrm{a}$, Constant means if all the variable $\mathrm{X}$ is not done, then there is still work satisfaction at 1.367. Compensation, has a positive value of 0.226 , which means that every $1 \%$ change in compensation will increase job satisfaction by 0.226 . Work discipline, positive value 0.602 , which means that every time there is a change in work discipline by $1 \%$, job satisfaction will increase by 0.602 . Work motivation, positive value 0.136 , which means that every change in work motivation by $1 \%$, job satisfaction will increase by 0.136 .

Table 5 . Multicolonierity Test Results

\begin{tabular}{lccl}
\hline \multicolumn{1}{c}{ Variabel } & Tolerance & VIF & \multicolumn{1}{c}{ Keterangan } \\
\hline Compensation & 0,675 & 2,160 & VIF $<10$ \\
Work Dicipline & 0,675 & 2,160 & Multicollinearity free \\
Work Motivation & 0,675 & 2,160 & \\
\hline
\end{tabular}

Source: SPSS Output

Table 5, it can be seen that the VIF value of all independent variables is less than 10 and the tolerance value is greater than 0.1 , so it can be concluded that there is no multicollinearity problem. The results of the heteroscedasticity test using spss showed that the dots were scattered irregularly, so it could be concluded that the regression model used in this study did not have a heteroscedasticity problem. 
Table 6. Test Results Simultanous

\begin{tabular}{llccccc}
\hline & Model & $\begin{array}{c}\text { Sum of } \\
\text { Squares }\end{array}$ & Df & $\begin{array}{c}\text { Mean } \\
\text { Square }\end{array}$ & F & Sig. \\
\hline $1 \quad$ Regression & 5,703 & 3 & 1,901 & 7,145 & $0,000 \mathrm{~b}$ \\
& Residual & 17,292 & 65 & 0,266 & & \\
\multicolumn{2}{l}{ Total } & 22,995 & 68 & & & \\
\hline
\end{tabular}

Source: SPSS output

Based on the SPSS output above, it is known that the significance level of the F test is 0,000 . This value is less than 0,05 . So it can be concluded that the variables of Compensation, Work Motivation, and Work Discipline together have a significant influence on Job Satisfaction. Based on table 4. It can be seen that the compensation has a significance level of $0,042<0,05$. So it is concluded that Compensation has a significant effect on Job Satisfaction, which means that the First Hypothesis is accepted. Based on table 4, it can be seen that the significance level of Work Discipline is $0,003<0,05$. It was concluded that the Discipline Working ber influence of sign ifikan on Job Satisfaction which means the second hypothesis is accepted. Based on the results of the SPSS analysis in table 4, it is shown that Work Motivation has a significance of 0,394 >0,05 . So it can be concluded that Work Motivation has an insignificant influence on Job Satisfaction, which means that the third hypothesis cannot be accepted.

Table 7. Test Results of Determination

\begin{tabular}{lcccr}
\hline Model & R & $\begin{array}{c}\text { R } \\
\text { Square }\end{array}$ & $\begin{array}{c}\text { Adjusted R } \\
\text { Square }\end{array}$ & Std. Error of the Estimate \\
\hline 1 & 0,498 & 0,748 & 0,213 & 0,51579 \\
\hline
\end{tabular}

Source: SPSS output

Based on Table 7. The results of the analysis show that the percentage contribution of the influence of the variable compensation, work motivation, and employee work discipline on job satisfaction of employees of PT.PP. Plantation Widodaren Jember, can be seen from the value of R Square (R2) shows at 0,748 or $74,8 \%$ and the remaining $25,2 \%$ influenced or explained by other factors that are not included in this research model, such as the Working Environment and characteristics of employees, etc.

Effect of Compensation on Job Satisfaction. Based on the results of the regression test, compensation has a significant effect on job satisfaction of employees of PT.PP Perkebunan Widodaren Jember. This can be seen from the level of significance of $0.042<0.05$. So that the first hypothesis is accepted. Employee welfare is greatly influenced by one of which is compensation, high or appropriate compensation to make employees feel satisfied so as to increase employee performance or productivity which indirectly impacts the effectiveness and efficiency of achieving company goals. The results of this study support the research conducted by Fitriani (2015) who found that compensation has a significant effect on Employee Job Satisfaction.

The Effect of Work Discipline on Job Satisfaction. Based on the results of the regression test, Work Discipline ber significant influence on employee Job satisfaction PT.PP Plantation Widodaren Jember. It can be seen from the $\mathrm{s}$ ignifikansi $0.003<0.05$. So that the second hypothesis is accepted. $\mathrm{H}$ al are due to the higher discipline of an employee, the employee is getting better in adjusting to the values and rules of the company, which will increase Ke discontent Work those employees. The results of this study support the research conducted by Arina (2015) who found that work discipline has a significant effect on job satisfaction. 
Effect of Work Motivation on Job Satisfaction. Based on the results of the regression test, it is known that Work Motivation has an insignificant effect on Job Satisfaction of PT.PP Perkebunan Widodaren Jember Employees. This can be seen from the significance level of $0.394>0.05$. H al is due to the comprehension and understanding of the company's management of the situation and conditions of employees on Work Motivation in PT. PP Perkebunan Widodaren Jember. Because based on information from the employees, that the management does not make approaches to employees so that the management does not know exactly the situation and conditions as well as the wants and needs of employees. This of course has an impact on employee performance which has decreased due to lack of attention and a touch of motivation to arouse employee morale. The results of this study are different from the results of Ekayadi's (2009) study which states that motivation has a significant effect on job satisfaction. This is because every motivation given by the leadership to employees affects and increases job satisfaction of employees of PT. Rimbajatiraya Citrakarya.

\section{CONCLUSION}

Based on the results of regression analysis, it can be seen that compensation and work discipline have a significant effect on employee job satisfaction at PT. PP Perkebunan Widodaren Jember. Meanwhile, the work motivation variable shows different results from the other two variables. Based on the research results, work motivation has no significant effect on employee job satisfaction. It is known that company management rarely takes approaches in order to motivate employees, so that employees are rarely given motivation which results in decreased employee productivity levels and this of course has an impact on the difficulty of achieving company goals effectively and efficiently.

Based on this, it can be suggested that PT. PP. Widodaren Jember Plantation should frequently approach employees with the aim of providing more motivation to employees. This can also be done by giving such as awards, bonuses, and so on with the aim of motivating employees to be better prepared to carry out their duties and obligations. For further research expected in order to enrich the research one of them with a way to add other variables that relate to matters that affect the increase in employee satisfaction . such as work environment, individual characteristics, and others.

\section{REFERENCE}

Imam, A., Purnamie., T. (2018). Influence Of Organizational Culture And Leadership Toward Commitment Of Organizational Committee At Al Jauhar Islamic Boarding School Sumbersari Jember. IJSTR . Vol 7, Issue 06, ISSN 2277-8616.

Arina, Y. (2015). The Effect of Work Environment and Work Discipline on Employee Job Satisfaction at CV. Yamaha Siteba Padang. Journal. Tamansiswa University: Faculty of Management Economics. Padang.

Armstrong, M. (2005). Human Resource Management. PT Elexmedia Komputindo. Jakarta. P. 43. As'ad, M. (2004). Industrial Psychology General Series; Human Resources. Yogyakarta: Liberty. Asmiarsih. (2006). Qualitative Research Methodology. PT Remaja Rosdaka rya. Bandung. P. 23

Astuti, A. J., Ketut, N. and Sudharma, I. N. (2013). The Effect of Compensation and Motivation on Employee Satisfaction and Performance at Bakung's Beach Cottages Kuta. Scientific journals. Udayana University: Faculty of Economics. Bali

Baron and Byrne. (2009). Factors affecting employee job satisfaction. Jakarta. Rineka Cipta.

Damayanti Retno. (2005). The influence of employee motivation on work productivity of CV. Bening Natural Furniture in Semarang.

Dessler, G. (2006). Human Resource Management. Tenth edition of volume I. Translation of Paramita Rahayu. Klaten: True Diamond. 
Dwihartono, D. (2010). The Effect of Compensation, Motivation, and Job Satisfaction on the Performance of Civil Servants in the Culture and Tourism Office of Semarang City. MM thesis journal. Diponegoro University: Faculty of Economics. Semarang.

Ekayadi, S. (2009). The Influence of Motivation and Career Development on Employee Job Satisfaction at PT. Rimbajatir Citrakarya. Article. Gunadarma University: Faculty of Economics. Jakarta.

Fathoni, A. (2006). Human Resource Management. Bandung: Rineka Cipta.

Fitriani, S, U. (2015). The Effect of Compensation, Motivation, and Work Discipline on Employee Performance of PT Taletama Artha Mandiri Pontianak. General journal. Tanjungpura Univrsitas: Faculty of Economics. Pontianak.

Ghozali, I. (2009). Application of Mutariate Analysis with the SPSS Program, Fourth Edition, Diponegoro University Publisher.

Handoko, T. H. (2008). Management of Personnel and Human Resources. Second Edition . Yogyakarta: BPFE.

Handoko, T. Hani. (2009). Motivation of Motivation for Motivation of Behavior. Canisius. Yogyakarta.

Hasibuan, M. (2006). Basic Management, Definition, and Problems. Jakarta: Earth Literacy. Pg 143

Hasibuan, M. (2010). Management of Human Resources. Revised edition. Jakarta: Earth Literacy.

Husein, U. (2011). Human Resources Research Design and Employee Behavior. Third print. PT. KING GRAFINDO PERSADA. Jakarta

Mahsun, M. (2012). Public Sector Performance Measurement, First Edition, BPFE Publisher: Yogyakarta

Mangkunegara, A. P. (2005). Company Human Resource Management. Bandung: Youth Resdakarya.

Mangkunegara, A. P. (2009). Human Resource Management for the Company. Bandung: Youth Resdakarya. P. 120

Margono. (2010). Educational Research Methodology, Jakarta: Rineka Cipta. Martoyo, Susilo. 2012. Job Satisfaction. PT Graha Ilmu. Yogyakarta. P. 115. Maslow, Abraham. 2008. Motivation and Personality. Banawan Library. Jakarta.

Mathis, R. L and Jakson, J. H. (2007). Human Resources Management. Publisher PT. Four Salemba. Jakarta. Pg, 89.

Megawati, S. (2005). Application of a compensation system. Erlangga. Jakarta. Mondy, R. Wayne. 2008. Human Resource Management. Issue Ten. Erlangga. Jakarta.

Oei, I. (2010). Research Human Resources he: Gramedia Pustaka Utama. Jakarta

Robbins, P. S. (2006). Organizational Behavior. Jakarta: Index.

Best regards, A .(2008). Human Resource Management. Cirebon: STAIN PRESS

Siagian, S. P. (2012). Human Resource Management. Volume I. Job satisfaction. Latent: Real Intan.

Sugiyono. (2008). Business Research Methods. Bandung: Transito Supranto.2001. Statistical Methods, LP3ES: Indonesia, Jakarta

Sutrisno. (2009). Discipline in an organization. PT Vale Indonesia Tbk. Jakarta.

Veithzal, Rivai and Sagala. (2011). Company Compensation . Gramedia Group. Jakarta.

Louis, W., A. (2012). The Effect of Compensation and Motivation on Employee Job Satisfaction and Its Impact on Employee Performance (Case Study at PT. Profilia Indotech Surabaya). Essay. Surabaya Development University. 